\title{
Down syndrome and congenital heart disease: perioperative planning and management
}

\author{
Dennis R. Delany ${ }^{1 *}$ D , Stephanie S. Gaydos², Deborah A. Romeo ${ }^{3}$, Heather T. Henderson', Kristi L. Fogg ${ }^{4}$,
} Angela S. McKeta ${ }^{1}$, Minoo N. Kavarana ${ }^{5}$ and John M. Costello ${ }^{1}$

\begin{abstract}
Approximately 50\% of newborns with Down syndrome have congenital heart disease. Non-cardiac comorbidities may also be present. Many of the principles and strategies of perioperative evaluation and management for patients with congenital heart disease apply to those with Down syndrome. Nevertheless, careful planning for cardiac surgery is required, evaluating for both cardiac and noncardiac disease, with careful consideration of the risk for pulmonary hypertension. In this manuscript, for children with Down syndrome and hemodynamically significant congenital heart disease, we will summarize the epidemiology of heart defects that warrant intervention. We will review perioperative planning for this unique population, including anesthetic considerations, common postoperative issues, nutritional strategies, and discharge planning. Special considerations for single ventricle palliation and heart transplantation evaluation will also be discussed. Overall, the risk of mortality with cardiac surgery in pediatric patients with Down syndrome is no more than the general population, except for those with functional single ventricle heart defects. Underlying comorbidities may contribute to postoperative complications and increased length of stay. A strong understanding of cardiac and non-cardiac considerations in children with Down syndrome will help clinicians optimize perioperative care and long-term outcomes.
\end{abstract}

Keywords: Down syndrome, Trisomy 21, Congenital heart disease, Congenital heart surgery, Perioperative management

\section{Background}

Down syndrome (DS) is the most common chromosomal abnormality with a prevalence of 11.8 per 10,000 live births [1]. Approximately 50\% of newborns with DS have congenital heart disease (CHD) [2, 3]. The vast majority of these heart defects require surgical or transcatheter intervention, most commonly in infancy. Although many of the principles and strategies of perioperative evaluation and management for patients with $\mathrm{CHD}$

\footnotetext{
* Correspondence: delanyd@musc.edu

1 Department of Pediatrics, Division of Pediatric Cardiology, Medical University of South Carolina, 10 McClennan Banks Drive, MSC915, Charleston, SC 29425, USA

Full list of author information is available at the end of the article
}

apply to those with DS, there are a number of specific issues that warrant special attention.

In this manuscript, for children with DS and hemodynamically significant CHD, we will summarize the epidemiology of heart defects that warrant intervention. We will review perioperative planning for this unique population, including anesthetic concerns, common postoperative issues, nutritional strategies, and discharge planning. Special considerations for single ventricle palliation and heart transplantation evaluation will also be discussed.

(c) The Author(s). 2021 Open Access This article is licensed under a Creative Commons Attribution 4.0 International License, which permits use, sharing, adaptation, distribution and reproduction in any medium or format, as long as you give appropriate credit to the original author(s) and the source, provide a link to the Creative Commons licence, and indicate if changes were made. The images or other third party material in this article are included in the article's Creative Commons licence, unless indicated otherwise in a credit line to the material. If material is not included in the article's Creative Commons licence and your intended use is not permitted by statutory regulation or exceeds the permitted use, you will need to obtain permission directly from the copyright holder. To view a copy of this licence, visit http://creativecommons.org/licenses/by/4.0/. The Creative Commons Public Domain Dedication waiver (http://creativecommons.org/publicdomain/zero/1.0/) applies to the data made available in this article, unless otherwise stated in a credit line to the data. 


\section{Methods}

The authors searched the published literature using a variety of medical subject terms to identify peerreviewed articles on perioperative care issues relevant to the management of patients with DS and CHD, ranging in age from neonates to adults. We focused on original manuscripts published since 2010 but included a number of earlier relevant publications. Non-full text publications or languages other than English were excluded.

\section{History of congenital heart surgery in patients with Down syndrome}

Although aggressive medical management and surgical intervention for $\mathrm{CHD}$ in patients with $\mathrm{DS}$ is routine practice in the current era, that was not always the case. John Langdon Down first described the features of DS in 1866 and Jerome Lejeune linked the syndrome to the chromosomal abnormality of trisomy 21 in 1959 [4]. Open heart surgery for most congenital heart defects became widely available in the 1960s and early 1970s. In the early years of congenital heart surgery, patients with DS were systematically not offered cardiac surgical intervention [5]. However, as outcomes for noncardiac conditions that afflict infants with DS improved and complete cardiac repair in infancy became more common for large septal defects, it was found that patients with DS generally tolerated surgery well. Societal attitudes changed, and increasingly more infants with DS and CHD were referred for surgery. Today, it is the standard of care to offer cardiac surgery to patients with DS with CHD that otherwise meet criteria for intervention.

\section{Epidemiology of CHD in patients with Down syndrome undergoing surgery}

DS is present in nearly $10 \%$ of all children undergoing cardiac surgery, including approximately $2 \%$ of neonatal cases $[6,7]$. Based upon statistics reported from the Society of Thoracic Surgeons Congenital Heart Surgery
(STS-CHS) Database, the most common surgical procedures performed in children with DS are summarized in Table 1 [6].

\section{Special considerations for perioperative planning}

Preoperative evaluation and planning for any patient being considered for a cardiac surgical procedure must be thorough and consider the patient's medical and surgical history, cardiac anatomy, and non-cardiac comorbidities. Additional details regarding cardiovascular disease and extracardiac comorbidities warrant specific attention when planning surgery for patients with DS and CHD.

\section{Simple left to right shunts}

Ventricular septal defect (VSD), atrial septal defect (ASD), and patent ductus arteriosus (PDA) are common types of CHD present in children with DS [6, 8, 9]. In patients with ASD and VSD, data from the STS-CHS Database indicate that those with DS were younger and weighed less for age at time of surgery compared with patients without genetic anomalies. Specifically, average ages at time of repair of ASD was 1.2 years versus 4.1 years, and average ages at time of VSD repair was 4.8 months versus 7.4 months (DS versus non-DS respectively) [6].

\section{Atrioventricular septal defects}

Due to the increased frequency of endocardial cushion defects with DS, evaluation of left to right shunts should specifically evaluate for inlet-type VSDs, primum-type ASDs, and partial, transitional, or complete atrioventricular septal defects (AVSD). With these defects, special attention should be given to assess for conoseptal malalignment in VSDs, additional muscular VSDs, and crossing atrioventricular valve chords in inlet-type VSDs.

Repair of complete AVSD is the most common cardiac procedure for patients with DS [6]. As with any preoperative cardiac work-up of complete AVSD, detailed

Table 1 Most common cardiac surgeries in patients with Down syndrome as summarized in the STS-CHS Database [6]

\begin{tabular}{lc}
\hline Procedure & \% of patients with Down syndrome \\
\hline Complete atrioventricular septal defect repair & 33 \\
Ventricular septal defect closure & 19 \\
Mitral valve repair/replacement & 7 \\
Partial atrioventricular septal defect repair & 6 \\
Patent ductus arteriosus ligation & 4 \\
Tetralogy of Fallot repair & 4 \\
Atrial septal defect closure & 4 \\
Coarctation/arch repair & 2 \\
Tricuspid valve repair/replacement & 2 \\
Tetralogy of Fallot- atrioventricular septal defect repair & 1 \\
\hline
\end{tabular}

STS-CHS Society of Thoracic Surgeons Congenital Heart Surgery 
evaluation should be completed of the common atrioventricular valve (AVV), ventricular balance, and ventricular outflow tracts. Structurally, patients with DS have lower rates of left AVV dysplasia (3\% with DS vs. $24 \%$ with non-DS), unbalanced ventricles (3\% with DS vs. $25 \%$ with non-DS), and left-sided obstructive lesions (1\% with DS vs. $30 \%$ with non-DS) when compared to those with complete AVSD without genetic anomalies [10-12]. Additionally, the AVVs in patients with DS are more likely to be Rastelli Type A, with a divided anterior bridging leaflet with connection to the crest of the ventricular septum [13]. Excluding a patent foramen ovale or a small additional secundum ASD, nearly half of patients with DS undergoing AVSD repair have one or more additional cardiac procedures performed intraoperatively, including PDA ligation, repair of aortic arch anomaly, closure of additional VSD, baffle of anomalous systemic venous drainage, repair of pulmonary venous stenosis, and subaortic stenosis resection [14].

Compared to patients without chromosomal abnormality, those with DS tend to present for AVSD repair surgery at the same age but lower average weight [6]. Growth failure at surgery is high at $71 \%$ for infants with DS versus $21 \%$ of those without chromosomal abnormality [14]. Of note, patients with DS tend to have significant catch up growth after surgery but a large proportion still have growth failure $(27 \%$ in DS vs. $7 \%$ in non-DS) [14].

\section{Tetralogy of Fallot}

In addition to endocardial cushion defects, the presence of conoseptal malalignment must also be evaluated. TOF or coexistent TOF and AVSD are more common in children with DS than in children without genetic abnormalities [6]. Overall, those with TOF are repaired around the same age but have a lower weight for age [6].

\section{Single ventricle palliation}

Single ventricle lesions are occasionally seen in patients with DS. Structurally, patients with DS are more likely to have left ventricle dominant lesions, while patients without DS are more likely to have right ventricle dominant or complex single ventricle lesions, including transposition of the great arteries or left-sided obstructive lesions $[15,16]$. Despite generally having more favorable anatomy for single ventricle palliation, the reported outcomes in the literature indicate that mortality is relatively high compared to patients without DS. A STSCHS Database study found that there was increased operative mortality in patients with DS at every stage of single ventricle palliation (Stage 1 palliation: 73\% in DS vs. $19 \%$ in non-DS, Glenn operation: $19 \%$ in DS vs. $2 \%$ in non-DS, and Fontan operation: $24 \%$ in DS vs. $2 \%$ in non-DS) [6]. Using Pediatric Cardiac Care Consortium
(PCCC) data, Petersen et al. showed that patients with DS and functional single ventricle heart defects had high in-hospital first-stage mortality at $24 \%$, and for those undergoing a Norwood procedure, specifically, hospital mortality was $68 \%$ [15]. These investigators also found that only $21 \%$ of patients included in the initial cohort completed the Fontan procedure, and of those who did not go to Fontan, $50 \%$ were ineligible due to hemodynamic or anatomic concerns [15]. The KaplanMeier Survival following each stage of single ventricle palliation for DS patients is depicted in Fig. 1.

Risk stratification in patients with DS and functional single ventricle heart defects can be challenging due to small sample sizes in most studies, but pulmonary hypertension $(\mathrm{PH})$ is likely one of the main contributing factors to mortality [6, 16, 17]. Colquitt et al. showed that patients with DS and single ventricle anatomy have minimal mortality beyond 2 years of age if their pulmonary vascular resistance (PVR) is less than 3 indexed Woods units in their first year of life [18]. In fact, when adjusting for PVR, this study found that DS is not associated with increased mortality compared to other nonsyndromic patients undergoing the single ventricle palliation at their center [18]. These data suggest that for patients with DS and functional single ventricle heart defects, careful patient selection is critical to achieving acceptable outcomes. One must consider the potential for decreased responsiveness to $\mathrm{PH}$ therapies found in patients with DS (described below) when planning on staged procedures [19-21]. In children with DS, performing a pulsatile Glenn operation or fenestrated Fon$\tan$ operation, if anatomy and hemodynamics allow, has been shown to decrease perioperative and late mortality [22]. If hemodynamics are borderline after Glenn procedure, one should strongly weigh the risks versus benefits of proceeding to Fontan, as one report suggested that Fontan completion was not associated with improved survival compared with sustained Glenn physiology [15].

\section{Pulmonary hypertension}

In patients with DS who are being evaluated prior to a cardiac operation, the work-up should closely evaluate for signs of $\mathrm{PH}$. More specifically, the concern should be for pulmonary vascular disease (PVD), meaning elevated pulmonary arterial pressures in the context of changes in the pulmonary vascular bed leading to increased PVR. Children with DS are at more than 20-fold greater risk for having $\mathrm{PH}$ when compared to the general population, and those with CHD are at even greater risk [23]. Lung disorders including relative underdevelopment of the pulmonary vascular bed (pulmonary hypoplasia) and chronic issues with upper airway obstruction are likely contributory (World Health Organization Group $3 \mathrm{PH}$ ). 


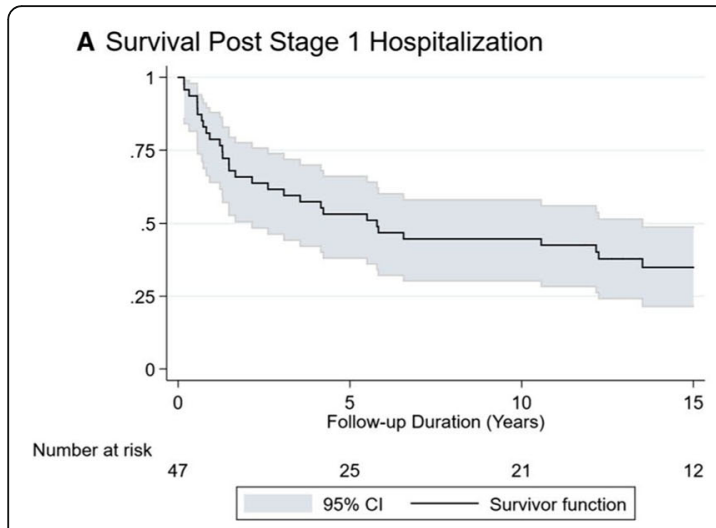

c Survival Post Fontan Hospitalization

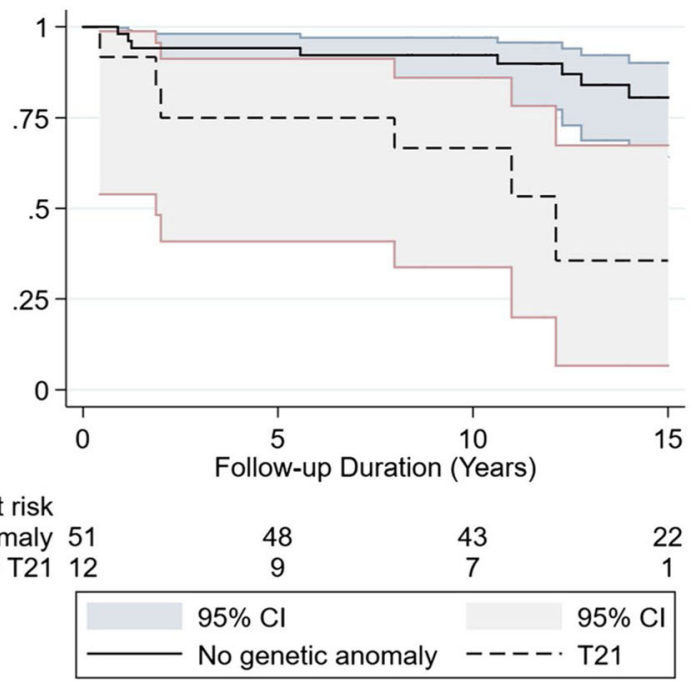

2 I
B Survival Post Glenn Hospitalization

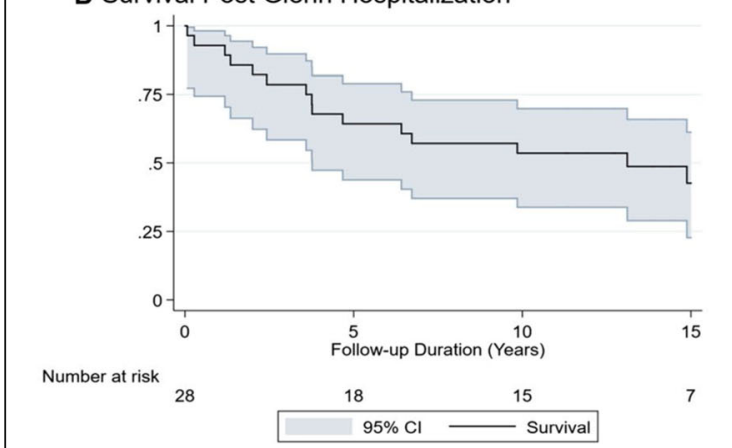

Number at risk No genetic anomaly 51 GeneticDx = T21 12

Fig. 1 Kaplan-Meier transplant-free survival plot conditioned on hospital discharge: a after the Stage 1 procedure in patients with DS with functional single ventricle heart defect, $\mathbf{b}$ after Glenn procedure in patients with DS with functional single ventricle heart defect, and $\mathbf{c}$ after Fontan procedure in patients with DS with functional single ventricle heart defect. DS, Down syndrome; Cl, Confidence interval [15]. (Used with permission)

Left to right intracardiac shunts with longstanding overcirculation create increased pulmonary artery pressure, shear stress, endothelial dysfunction, vascular remodeling, and altered vasoactive mediator expression (World Health Organization Group $1 \mathrm{PH}$ ). Additionally, patients with obstructed pulmonary venous return, mitral stenosis, or left ventricular outflow obstruction (critical aortic valve stenosis or coarctation of the aorta) may develop increased PVR (World Health Organization Group $2 \mathrm{PH}$ ).

Studies from the early 1990s have shown higher PVR that is more likely to be irreversible in DS patients, and this phenomenon may develop as early as 6 months of age $[24,25]$. These observations have been correlated more recently in a STS-CHS Database report which found higher rates of $\mathrm{PH}$ present in patients with ASDs or VSDs and DS compared to those without genetic anomalies [6]. Surprisingly, higher rates of $\mathrm{PH}$ were not found in patients with AVSD and DS, likely related to the fact that, in the current era, most undergo repair within the first 6 months of life [6]. In fact, early definitive repair (i.e., within the first 6 months of life) can reduce the incidence of postoperative $\mathrm{PH}$ [26]. A combination of anecdotal experience and data from early case series has prompted most centers into performing complete AVSD and large VSD repairs at 4-6 months of age.

Clinically, suspicion for $\mathrm{PH}$ should be increased in children with anatomically large left to right shunts if there is a lack of signs and symptoms of pulmonary overcirculation, lack of failure to thrive, or if increasing cyanosis is present. By echocardiogram, evidence of $\mathrm{PH}$ can be shown using a variety of methods depending on the type of lesion. In the presence of a restrictive VSD or intact ventricular septum without right ventricular outflow tract obstruction (RVOTO), signs of PH include a tricuspid regurgitation jet estimating right ventricular pressure greater than half systemic or by intraventricular septal flattening. If there is a nonrestrictive VSD or large PDA, PH may be suggested by right to left shunting at ventricular or great vessel level (in the absence of RVOTO) or an elevated early diastolic pulmonary regurgitation gradient. Finally, in the absence of left sided obstructive lesions, right to left shunting at the level of the PDA may also provide evidence of PH. As shown by the number of caveats based on type of CHD noted above, these echocardiographic findings only suggest that PVR is elevated. If there is clinical or echocardiographic 
evidence of $\mathrm{PH}$ or the patient is older with a longstanding left to right shunt lesion, then cardiac catheterization should be considered to quantify PVR, and, if it is elevated, pulmonary vaso-reactivity testing with oxygen and nitric oxide is typically performed. Alternatively, given the risks associated with cardiac catheterization, an infant with initial predominant right to left shunting can be placed on oxygen while in clinic, observed to see if the oxygen saturation increases, and the direction of the shunt on echo can be reassessed. If the direction of the shunt reverses becoming left to right, a cardiac catheterization can likely be avoided. Of note, there is some evidence that patients with DS may have less response to pulmonary vasodilators, including nitric oxide [20]. In the STARTS trial, sildenafil was tolerated well in patients with DS, but led to little improvement of PVR [19]. Similarly, in a study by Duffles et al., bosentan did not have an effect on exercise capacity or quality of life in adults with pulmonary arterial hypertension related to CHD and DS [21].

Following cardiopulmonary bypass (CPB), $\mathrm{PH}$ may be caused by a combination of preoperative, intraoperative, and postoperative factors. DS is a known risk factor for severe postoperative $\mathrm{PH}$ [27]. Yet, even in the absence of DS, CPB is associated with increased PVR in infants and children [28-30]. The presence of significant $\mathrm{PH}$ soon after weaning from $\mathrm{CPB}$ is predictive of subsequent $\mathrm{PH}$ in the ICU and the need for prolonged ventilatory support. Residual lesions, including large left to right shunts, obstruction to pulmonary venous or distal pulmonary arterial blood flow, or left-sided obstructive lesions may cause PH. Noxious stimuli, particularly suctioning of the endotracheal tube, may trigger a pulmonary hypertensive crisis. PH may manifest as low cardiac output following a biventricular repair, particularly when both septa are completely intact, or as excessive cyanosis in patients with palliated single ventricle physiology. In general, children with $\mathrm{PH}$ are at increased risk of perioperative complications [31, 32]. A combination of relatively simple postoperative strategies should be sufficient both to prevent and to treat pulmonary hypertensive crises in many at-risk patients (Table 2) [33].

\section{Non-cardiac comorbidities}

Features of DS may manifest in nearly every organ system, and thus a comprehensive assessment is required prior to taking a patient with DS to the OR [34]. Specifically, one should consider the potential for problems within the gastrointestinal, respiratory, immunologic, hematologic, endocrine, and neurologic systems. Generally, clinicians involved in preoperative evaluation should refer to the American Academy of Pediatrics guidelines
Table 2 Critical care strategies for treatment of PH [33]

\begin{tabular}{ll}
\hline Encourage & Avoid \\
\hline 1. Anatomic investigation & 1. Residual anatomic disease \\
2. Right to left atrial pop off & 2. Intact atrial septum \\
3. Sedation/analgesia & 3. Agitation/pain \\
4. Moderate hyperventilation & 4. Respiratory acidosis \\
5. Moderate alkalosis & 5. Metabolic acidosis \\
6. Adequate inspired oxygen & 6. Alveolar hypoxia \\
7. Normal lung volumes & 7. Atelectasis or overdistension \\
8. Optimal hematocrit & 8. Excessive hematocrit \\
9. Inotropic support & 9. Low output and coronary perfusion \\
10. Pulmonary vasodilators & 10. Pulmonary vasoconstrictors \\
\hline
\end{tabular}

for "Health supervision for children with Down syndrome" for age-appropriate screening [35].

\section{Gastrointestinal}

After CHD, abnormalities of the gastrointestinal tract are the most common anomaly associated with DS, being present in $6 \%$ of cases in one large European registry study [9]. These include duodenal atresia, duodenal webbing, annular pancreas, anal atresia, Hirschsprung disease, and tracheoesophageal fistula/esophageal atresia. If there are feeding concerns preoperatively or the neonate fails to pass meconium, there should be a low threshold to further evaluate for these anomalies.

\section{Respiratory}

The respiratory manifestations of DS contribute significantly to morbidity and reduced survival in this population [36-38]. The anatomic features are discussed below in the section on anesthesia management. Functionally, obstructive sleep apnea (OSA) has a high prevalence of about $76-97 \%$ in children with DS who snored and 55\% in those without snoring $[39,40]$. The risk of OSA increases with BMI and age [41], although OSA may be more severe if it presents earlier [40]. If OSA is found preoperatively, consideration for adenotonsillectomy should be taken, although the timing of that procedure relative to an upcoming cardiac operation will require clinical judgment. Children with DS and OSA who underwent adenotonsillectomy showed significant improvement of obstructive and central apneic indices [42-45]. Additionally, OSA likely plays a long-term role in the development of $\mathrm{PH}$, and adenotonsillectomy may help halt or reverse the progression of $\mathrm{PH}$ and right heart disease [46, 47].

\section{Immunologic/hematologic}

Children with DS are also more likely to develop infections and to take longer to recover from them [48, 49]. Multiple factors are contributory, as children with DS 
may have abnormalities of the immune system with $\mathrm{T}$ and B cell lymphopenia, secondary immunodeficiency due to nutritional and metabolic factors, and anatomic abnormalities with small ear canals, tracheomalacia, tracheal bronchus, and gastroesophageal reflux [48]. Overall, the most frequent type of infections involve the respiratory tract, especially the upper respiratory tract $[49,50]$. Additionally, patients with DS and acute respiratory tract infection are more likely to develop acute lung injury or acute respiratory distress syndrome [51]. Careful history for recent infections or history of infections requiring hospitalization should be obtained preoperatively.

Neonates with DS can have neutrophilia, thrombocytopenia/thrombocytosis, polycythemia transient myeloproliferative disorder, and congenital leukemia [52]. Children with DS have a 20 -fold increased risk of leukemia, with acute myeloblastic leukemia as the most common type, and the highest incidence occurs in children younger than 5 years [53]. Interestingly, although the rates of blood cancers are higher in children with DS, most other cancers tend to be lower than non-DS population $[53,54]$. For these reasons, a complete blood count should be obtained before surgery, and abnormal blood counts should be discussed with hematologist.

\section{Endocrine}

Thyroid disorders are common in DS. Hypothyroidism has a prevalence of $4-18 \%[55,56]$. If not assessed on the state newborn metabolic screen, TSH should be obtained in the neonatal period. The risk for hypothyroidism increases with age, and TSH should be followed annually $[35,57]$. Dry skin, thin hair, poor appetite, constipation, poor energy, hypotonia, bradycardia, and behavior changes may be signs of hypothyroidism, but are not always present [58]. Thyroid hormones are important for cardiovascular effects of decreasing afterload and increasing heart rate, preload, and contractility. If there are any signs or symptoms of hypothyroidism or a level has not been recently checked, consider checking a TSH with preoperative labs.

Though not generally a problem in the operative room, hypothyroidism can contribute to hypotension post-operatively and is easily treated with triiodothyronine therapy when identified. Cardiopulmonary bypass has been shown to decrease thyroid hormone levels [59]. A triiodothyronine level less than 0.6 has been associated with longer mechanical ventilation and ICU LOS, with higher vasoactive drip and furosemide cumulative doses [59]. A separate study however, showed no significant cardiac impairment in patients with DS and subclinical hypothyroid [60]. Additionally, replacement of triiodothyronine post-bypass has shown little benefit [61]. Overall, the literature does not support routine use of intraoperative or early postoperative triiodothyronine supplementation, but larger studies are needed.

\section{Neurologic}

The degree of cognitive impairment can range from mild (intelligence quotient 50-70) to severe (intelligence quotient 20-35) [35]. Clinicians should also be aware of the $1-13 \%$ prevalence of seizures and frequent hearing and vision impairment with a prevalence of $60-75 \%$ [35]. Preoperatively, it is useful to understand the child's cognitive function, likes and dislikes, and any physical handicaps, and to deliver this information to the anesthesia and postoperative care teams.

\section{Adults with Down syndrome and congenital heart disease} Special attention should be allocated to the surgical and anesthetic preoperative assessment for adult patients with DS undergoing congenital cardiac surgery. As described above, comorbidities such as obstructive sleep apnea, hypothyroidism, and epilepsy occur with high frequency and may significantly impact a patient's perioperative course [62]. Hypothyroidism can develop slowly over time, and can be difficult to detect clinically in adults with DS given overlapping symptomatology with other aging processes $[63,64]$.

Despite possessing increased rates of many traditional risk factors for acquired cardiovascular disease such as obesity, diabetes, sedentary lifestyle, and evidence of early aging within other organ systems, atherosclerosis is surprisingly uncommon in adults with DS [65-68]. In contrast to the general population of adults with similar risk profiles undergoing cardiac surgery, there is no recommendation for specific preoperative screening for coronary artery disease in adults with DS. As mentioned, diabetes does occur more commonly in patients with DS and would require additional perioperative monitoring and treatment to maintain goal glucose levels [69]. The team should note patients' fasting serum glucose levels on preoperative labs and, if elevated, consider additional lab screening with a hemoglobin A1C.

There should be a high suspicion for dementia in patients with DS over 40 years of age. Alzheimer's disease occurs in nearly $25 \%$ of adults with DS ages 40 to 49 years and in up to $55 \%$ of those ages 50 to 59 years [70]. Preexisting dementia is a significant risk factor for delirium in subacute care settings, and delirium confers broadly worse clinical and functional patient outcomes [71]. Identification of baseline dementia is additionally relevant when considering expected patient behavior and communication strategies postoperatively. Similarly, preoperative inquiry of visual and hearing abilities is important given prevalence of sensorineural hearing loss and early cataract formation in adults with DS [62]. Lastly, there should be close inspection of dental health 
on a preoperative assessment given the higher frequency of gingivitis and periodontal disease in adults with DS [72]. Such dental issues may raise a patient's risk of spontaneous bacterial endocarditis postoperatively and, if possible, should be treated prior to certain cardiothoracic interventions.

\section{Cardiac transplantation in children with Down syndrome}

Sometimes surgical repair or palliation is not a good option for patients with DS, and heart transplant may be considered. There is wide variation among transplant centers of how intellectual and developmental disabilities are factored into transplant evaluations and determination of candidacy. However, denying a patient with DS that would otherwise benefit from transplant the possibility of the same evaluation as a non-DS patient is unjust and prohibited by Americans with Disabilities Act (ADA) [73]. In 1995, Sandra Jensen, a 34 year-old with DS and CHD was denied heart-lung transplant solely based on her underlying chromosomal abnormality. After a national campaign protesting this discrimination, she underwent successful transplant in 1996, becoming the first patient in the world with DS to receive a lifesaving organ transplant $[73,74]$.

Since this time, several small studies report patients with DS receiving successful solid organ transplants with equivalent outcomes to non-DS patients [73, 75-78]. Intellectual disability alone does not affect short- and medium-term outcome in children after heart transplant, supporting the concept that intellectual delay that occurs in DS should not alone impact eligibility for transplant [78-81]. Overall, little is known specifically about heart transplant outcomes in patients with DS. A study by Broda, et al. evaluated cardiac transplant outcomes in children with various chromosomal abnormalities and found only 64 of 3080 (2\%) pediatric heart transplants were performed in children with various chromosomal abnormalities, and only five of these patients had DS, one of whom died prior to hospital discharge. Given the small numbers it was hard to make conclusions about prognosis [76].

Although intellectual disability should not preclude patients with DS from a thorough transplant evaluation and possible listing, many other factors need to be considered. Given the scarcity of donor organs, potential transplant recipients undergo a rigorous evaluation to determine their candidacy for transplantation. The evaluation goals are to determine whether a patient that meets medical criteria for transplant would benefit from the transplant surgical procedure and would also tolerate post-transplant medical therapies to extend both the quantity and quality of life. The evaluation must consider medical co-morbidities and behavioral and psychosocial factors.
All patients undergo evaluation of their other organ systems as part of the transplant evaluation process. Of particular concern is underlying pulmonary and renal dysfunction, as well as the strength of the immune system given increased risk of infection, hematologic abnormalities and malignancy post-transplant [9, 81-83]. Significant PVD is a relative contraindication for heart transplant. It is well known that DS is associated with an increased risk of malignancy, especially leukemia/lymphoma, some of which may ultimately be treated with bone marrow transplantation. These patients have worse outcomes compared to their non-DS leukemia patients [84]. Other hematologic and immunologic abnormalities have been reported in DS including a higher prevalence of anemia, including aplastic anemia, as well as underlying immune dysfunction increasing the risk of infections, duration of infections and complication rate from various infections [48, 85-88]. Although these comorbidities are significant, they are not absolute contraindications to heart transplant. However, the risks must be considered, especially when multiple organ-systems are involved. These diseases are equally important in the posttransplant period and may require avoidance of induction therapy and alteration of maintenance immunesuppressive therapy long term. Increased screening for infection, hematologic abnormalities and for malignancy should be performed.

In addition to medical co-morbidities, DS patients' families and support systems are a crucial part in the evaluation process. Education of families about the individual patient's risks and potential benefits of transplantation is an essential part of the evaluation process so they can make the best decision for their family. There are some families that may decide they are not equipped to carry the life-long burden of post-transplant care and should be supported in making that decision. However, if the family is interested, patients with DS and end-stage heart failure refractory to medical and other surgical therapies should be evaluated for heart transplant, regardless of underlying Trisomy 21 and intellectual disability. Patients with DS should not be denied access to a scarce resource based on their syndrome or disability, despite earlier practice and underlying bias about providers' perceived quality of life in DS patients $[73,89,90]$.

\section{Intraoperative management and anesthesia}

As is evident from the proceeding paragraphs, the implications of DS when considering an anesthetic are vast and require additional assessment and management [91].

\section{Upper airway obstruction}

Patients with DS have a high incidence of upper airway obstruction. Characteristic anatomic features include 
flattened nasal bridge, mid face and mandibular hypoplasia, macroglossia, soft palate hyperplasia, tracheal bronchus, tracheal and subglottic stenosis, as well as laryngomalacia and tracheomalacia [92, 93]. Further contributing to upper airway obstruction are tonsillaradenoidal hypertrophy, pharyngeal muscle hypotonia, and obesity affecting the soft tissues of the airway. These features together can lend to upper airway obstruction or complete collapse upon induction of general anesthesia [94]. For this reason the anesthesia provider must be prepared with oral and nasal airways to help facilitate bag mask ventilation, readily use positive pressure ventilation to help stent lax tissues open and be prepared for a challenging laryngoscopy by having additional airway equipment available. Upon emergence from general anesthesia, patients with DS and preexisting upper airway obstruction may continue to have upper airway obstruction which can be exacerbated by sedatives and analgesics, and thus the need for postoperative ventilatory support will need to be evaluated in these situations [31, 92]. When considering subglottic stenosis an appropriately sized endotracheal tube needs to be selected and a cuff leak auscultated at $20 \mathrm{mmHg}$ [95]. An inappropriately oversized endotracheal tube can lead to post-extubation stridor.

\section{Cervical spine instability}

There is a risk of atlantoaxial and atlanto-occipital instability in patients with DS. The rate of occurrence varies widely in the literature. Identification of patients with instability is a challenge, as very few of these patients will show symptoms and obtaining adequate imaging is difficult. Previously the American Academy of Pediatrics recommended lateral cervical spine X-rays for children with DS between 3 and 5 years of age, but recent guidelines no longer support this recommendation for asymptomatic children [35]. In the absence of clear guidelines, some providers recommend performing a thorough neurologic exam in patients with DS presenting for general anesthesia that will require instrumentation of the airway [91]. If an abnormality in exam is identified, the need for further imaging should be discussed between the anesthesia provider and the surgeon. When instrumenting the airway, consideration should be made to maintain in-line neck stabilization or consider a fiberoptic intubation.

\section{Hemodynamic changes with anesthesia}

Independent of structural cardiac disease, patients with DS experience hemodynamic changes upon inhalation induction of general anesthesia. They experience a higher incidence of bradycardia with a sevoflurane inhalation induction than do patients without DS $[31,96,97]$. For this reason some practitioners will pre-treat with atropine or glycopyrrolate. Some patients with DS can present a challenge with vascular access and as such an intramuscular dose of atropine may be required on induction of anesthesia [96].

\section{Gastrointestinal}

Patients with DS have a higher rate of duodenal obstruction. These patients often present to the operating room dehydrated with electrolyte abnormalities. They frequently require a rapid sequence induction to secure their airway and avoid aspiration. Intraoperative resuscitation and management of electrolytes is often necessary [31].

\section{Cardiopulmonary bypass}

Little data exists on differences on cardiopulmonary bypass between patients with and without DS. STS-CHS data shows slightly longer cardiopulmonary bypass and cross-clamp time for VSD closures in patients with DS, slightly shorter times for ASD repairs, but no significant difference in AVSD or TOF repairs [6].

\section{Postoperative care}

\section{Morbidity and mortality}

Since children with DS started undergoing cardiac surgery, many studies have compared their operative outcomes. Overall, most studies have found that operative mortality for patients with DS is the same or better than their peers with normal chromosomes [6, 12, 98-101]. Of note, the majority of these studies focused on patients undergoing biventricular repairs. As discussed earlier, patients with functional single ventricle heart defects and DS have decreased long-term survival. Despite good mortality outcomes in biventricular repairs, patients with DS may have increased postoperative complications and length of stay $[6,98,99,102]$. Postoperative complications may include infection, respiratory complications, reintubation, prolonged ventilation, $\mathrm{PH}$, renal insufficiency, and chylothorax. Many of these complications can be attributed to underlying comorbidities, as discussed earlier. For example, the increased rate of chylothorax is likely related to abnormalities of the lymphatic system more common in children with DS [103]. Despite a propensity to develop this postoperative complication, patients with chylothorax and DS generally have the same mortality, time in ICU, and duration of hospital stay as those patients with chylothorax and without DS [101].

\section{Down syndrome-specific post-operative cardiac complications}

The importance of chromosome 21 with embryonic heart development is evident in the prevalence of CHDs in individuals with DS. This fact lends to further 
question syndromic implications in cardiac-specific postoperative outcomes. Studies surmise that reoperation on residual cardiac lesions is no more likely in patients with DS compared to normal karyotype patients. Furthermore, there are some compelling claims that patients with DS in fact have better freedom from reoperation. Despite being typically younger and of lower weight than non-DS patients at time of surgery [6], patients with DS have demonstrated lower rates of reoperation after all types of cardiac surgical repair compared to nonsyndromic patients [12]. This was especially true for mitral valve surgery, prosthetic replacement, and recurrent subaortic stenosis. Other assessments specific to postoperative outcomes following AVSD repairs show conflicting results. Some demonstrate no differences in post-operative left atrioventricular valve dysfunction between patients with DS and those without DS [104, 105], while others showed significantly less need for valve reoperation in patients with DS [10, 106]. Overall, the available data indicate that the DS population is not expected to have higher rates of reoperation following CHD repair compared to non-syndromic patients.

One interesting caveat among post-operative outcomes in patients with DS is the risk of damage to the cardiac conduction system. Postoperative heart block resulting in permanent pacemaker placement seems to occur more commonly in DS patients undergoing VSD closure than normal karyotype patients, with DS being independently predictive of this outcome when accounting for patient age or weight at surgery $[6,107]$. The reason behind this finding remains unclear as there are no known anatomic abnormalities of the conduction system in patients with DS with perimembranous VSD. One possible explanation is that the perimembranous VSD may have some inlet extension and therefore displace the atrioventricular node inferiorly. The repair should be approached with the same precautions one would take while closing the ventricular septum component of a complete AVSD. There is atypical development of the atrioventricular node and ventricular conduction system in patients with DS with AVSD [108]. Studies have not consistently shown increased prevalence of complete heart block or other significant bradyarrhythmia in patients with DS after AVSD repair versus nonsyndromic patients, including early and long-term follow-up [109-111].

\section{ECMO}

Extracorporeal membrane oxygenation (ECMO) may be used to provide circulatory support for children with DS who are recovering from cardiac surgery. Data from the Extracorporeal Life Support Organization (ELSO) Registry indicate that the use of ECMO for cardiac support in children with DS has increased in recent years [112]. Of 300 children with DS whose data were entered into the ELSO Registry after receiving ECMO support for a cardiac indication between 1983 and 2013, 136 (39\%) survived to hospital discharge [112]. The most common underlying cardiac diagnoses in these patients were partial or complete AVSD (38\%) and TOF (13\%) [112]. In another analysis of ELSO Registry data from 1998 through 2011, Gupta et al. compared children with DS who underwent cardiac surgery and were supported with ECMO $(n=121)$ with the children supported by ECMO post-cardiac surgery who did not have DS $(n=2694)$. They found that the patients with DS were older than the control group (median 133 vs 41 days), and that mortality was lower in the DS group (44\%) compared with the control group (55\%; $p=0.01$ ) [113]. These survival rates are similar though to those reported for all patients with CHD in the ELSO registry, for whom survival to hospital discharge is $54 \%$ [114].

\section{Pain control}

Pain control is an important component of postoperative management of children with DS. These patients often have a reputation for being difficult to sedate or requiring large amounts of pain medications. Multiple studies have evaluated this belief, showing some evidence that alteration in the cerebral cortex concentration in opioids and opioid receptors may exist in children with DS [115]. Gakhal, et al. found that the average rate of continuous morphine infusion after cardiac surgery was higher in the DS group, although this was not statistically or clinically significant until the third postoperative day, when patients with DS were more likely to still be receiving morphine [116]. They also showed the patients with DS were more likely to receive additional sedatives and skeletal muscle relaxants [116]. On the contrary, other studies evaluating cardiac and non-cardiac surgeries have shown similar overall opioid usage in patients with DS to those without DS [117, 118]. Additionally, the pharmacokinetics and pharmacodynamics of opioids in patients with DS versus those without DS do not significantly differ $[119,120]$. Similarly, alternatives to opioids, such as acetaminophen, have similar pharmacokinetics in patients with and without DS [121]. Finally, dexmedetomidine is another sedative medication that is both safe and efficacious in patients with and without DS, although younger patients with DS may be more likely to experience significant bradycardia [122].

\section{Nutrition considerations}

In the neonatal period, all patients with DS have higher incidence of low birth weight, hypotonia, impaired oral motor function, hypothyroidism, and gastrointestinal abnormalities that can contribute to poor growth [123- 
125]. Weight for age at time of cardiac surgery is often lower for patients with DS for all procedures, but this issue may also be an indication for earlier surgical referral [6]. Though impaired weight and height of children with DS and CHD are common, they have been shown to recover to normal values within 6 months post operatively [126].

Placement of gastrostomy tubes before or after cardiac repair is often necessary for the optimization of nutrition and growth in patients with DS, particularly in patients with AVSD and TOF [127, 128]. However, gastrostomy tube placement rate in patients with DS and CHD is similar to rate in DS patients without CHD [124]. When estimating energy requirements in infants with DS, resting energy expenditure (REE) without surgical repair is slightly lower due to decreased muscle tone [129]. This finding has not been replicated in CHD literature, as patients with chromosomal abnormalities are often excluded from these studies. Close attention should be paid to post-operative anthropometrics to avoid overfeeding in this population.

In adolescence and adulthood, patients with DS have a higher prevalence of overweight and obesity. Malnutrition followed by overweight and obesity may enhance risk to cardiovascular health compared to maintaining the same nutrition status over a period of time [130]. Use of DS specific growth charts are important for nutrition screening to accurately assess for both undernutrition and overweight/obesity and therefore to design a more targeted intervention [125]. In the post-operative adolescent or adult with DS, managing acute needs and transitioning to a general well-balanced diet with regular physical activity is important for prevention of longerterm cardiovascular disease [131].

\section{Discharge planning}

Several considerations should be made when preparing patients with DS for hospital discharge following cardiac surgery. As previously stated, patients with DS are more susceptible to bacterial and viral infections, attributed to a disordered immune system [132]. Additionally, viral respiratory infections may have profound effects on patients with CHD [133]. Patients with DS are particularly at high risk of severe respiratory syncytial virus (RSV) infection and worse outcomes when compared to patients without DS [134]. Careful and thorough education should be provided to parents regarding preventative measures to reduce exposure to seasonal viruses, the importance of adhering to the recommended immunization schedule, and, if applicable, inclusion criteria for Palivizumab, a humanized monoclonal antibody used for prophylaxis against RSV [134].

For neonates who have never been discharged to home, discharge planning should include referrals to developmental clinics specializing in DS care and therapeutic services such as occupational, physical and speech therapies. Available resources including local chapters affiliated with the National Down Syndrome Society and other local support groups should be provided to parents [135].

\section{Conclusions}

DS is a common chromosomal anomaly frequently associated with CHD. It also has broad effects on nearly all other body systems. Careful planning for cardiac surgery is required, evaluating for all cardiac and noncardiac disease, with careful consideration of the risk for PVD. Overall, the risk of mortality with cardiac surgery is no more than the general population, except for those with functional single ventricle heart defects. Underlying comorbidities may have a role in increased postoperative complications and increased length of stay. Communication with family to learn the patient's history as well as to discuss risks is essential. Cardiac surgery and perioperative care of the patient with DS and CHD has progressed significantly in the past 50 years. Future advancements will likely involve improved $\mathrm{PH}$ management, greater understanding of heart transplant in patients with DS, development of better medical and surgical management of single ventricles, and enhanced coordination of care for these complex patients.

\section{Acknowledgements \\ None.}

Authors' contributions

DRD and JMC conceptualized and developed the outline for the manuscript and performed initial critical review. DRD, DAR, JMC, SSG, HTH, KLF, and ASM were major contributors in writing the manuscript. MNK critically reviewed the manuscript. All authors read and approved the final manuscript.

Funding

The authors declare that they have no sources of funding.

Availability of data and materials

Not applicable.

\section{Declarations}

Ethics approval and consent to participate

Not applicable. This is a review article and therefore did not require institutional review board approval.

\section{Consent for publication}

Not applicable.

\section{Competing interests}

The authors declare that they have no competing interests.

\section{Author details}

'Department of Pediatrics, Division of Pediatric Cardiology, Medical University of South Carolina, 10 McClennan Banks Drive, MSC915, Charleston, SC 29425, USA. ${ }^{2}$ Department of Medicine, Division of Cardiology, Medical University of South Carolina, 30 Courtenay Drive, MSC 592, Charleston, SC 29425, USA.

${ }^{3}$ Anesthesia and Perioperative Medicine, Division of Pediatric Anesthesia, Medical University of South Carolina, 10 McClennan Banks Drive, MSC940, Charleston, SC 29425, USA. ${ }^{4}$ Department of Food and Nutrition, Sodexo, 
Medical University of South Carolina, 10 McClennan Banks Dr., MSC915, Charleston, SC 29425, USA. ${ }^{5}$ Department of Surgery, Division of Pediatric Cardiothoracic Surgery, Medical University of South Carolina, 10 McClennan Banks Dr., MSC915, Charleston, SC 29425, USA.

\section{Received: 23 October 2020 Accepted: 6 April 2021 \\ Published online: 20 April 2021}

\section{References}

1. Shin M, Besser LM, Kucik JE, Lu C, Siffel C, Correa A. Prevalence of Down syndrome among children and adolescents in 10 regions of the United States. Pediatrics. 2009;124(6):1565-71.

2. Irving CA, Chaudhari MP. Cardiovascular abnormalities in Down's syndrome: spectrum, management and survival over 22 years. Arch Dis Child. 2012; 97(4):326-30. https://doi.org/10.1136/adc.2010.210534.

3. Weijerman ME, van Furth AM, Vonk Noordegraaf A, van Wouwe JP, Broers CJ, Gemke RJ. Prevalence, neonatal characteristics, and first-year mortality of Down syndrome: a national study. J Pediatr. 2008;152(1):15-9. https://doi. org/10.1016/j.jpeds.2007.09.045.

4. Mégarbané A, Ravel A, Mircher C, Sturtz F, Grattau Y, Rethoré MO, et al. The 50th anniversary of the discovery of trisomy 21: the past, present, and future of research and treatment of Down syndrome. Genet Med. 2009; 11(9):611-6. https://doi.org/10.1097/GIM.0b013e3181b2e34c.

5. Sondheimer HM, Byrum CJ, Blackman MS. Unequal cardiac care for children with Down's syndrome. Am J Dis Child. 1985;139(1):68-70. https://doi.org/1 0.1001/archpedi.1985.02140030070032.

6. Fudge JC Jr, Li S, Jaggers J, O'Brien SM, Peterson ED, Jacobs JP, et al. Congenital heart surgery outcomes in Down syndrome: analysis of a national clinical database. Pediatrics. 2010;126(2):315-22. https://doi.org/10.1 542/peds.2009-3245.

7. Patel A, Costello JM, Backer CL, Pasquali SK, Hill KD, Wallace AS, et al. Prevalence of noncardiac and genetic abnormalities in neonates undergoing cardiac operations: analysis of the Society of Thoracic Surgeons congenital heart surgery database. Ann Thorac Surg. 2016;102(5):1607-14.

8. Freeman SB, Bean LH, Allen EG, Tinker SW, Locke AE, Druschel C, et al. Ethnicity, sex, and the incidence of congenital heart defects: a report from the National Down syndrome Project. Genet Med. 2008;10(3):173-80. https://doi.org/10.1097/GIM.0b013e3181634867.

9. Stoll C, Dott B, Alembik Y, Roth MP. Associated congenital anomalies among cases with Down syndrome. Eur J Med Genet. 2015;58(12):674-80. https://doi.org/10.1016/j.ejmg.2015.11.003.

10. Al-Hay AA, MacNeill SJ, Yacoub M, Shore DF, Shinebourne EA. Complete atrioventricular septal defect, Down syndrome, and surgical outcome: risk factors. Ann Thorac Surg. 2003;75(2):412-21. https://doi.org/10.1016/S0003-4 975(02)04026-2.

11. De Biase L, Di Ciommo V, Ballerini L, Bevilacqua M, Marcelletti C, Marino B. Prevalence of left-sided obstructive lesions in patients with atrioventricular canal without Down's syndrome. J Thorac Cardiovasc Surg. 1986;91(3):4679. https://doi.org/10.1016/S0022-5223(19)36064-7.

12. Formigari R, Di Donato RM, Gargiulo G, Di Carlo D, Feltri C, Picchio FM, et al. Better surgical prognosis for patients with complete atrioventricular septal defect and Down's syndrome. Ann Thorac Surg. 2004;78(2):666-72; discussion 72. https://doi.org/10.1016/j.athoracsur.2003.12.021.

13. Cetta F, Truong D, Minich LL, Maleszewski JJ, O'Leary PW, Dearani JA, et al. Atrioventricular Septal Defects. In: Allen H, editor. Moss \& Adams' heart disease in infants, children, and adolescents, including the Fetus and Young Adult: Wolters Kluwer Health; 2016.

14. Atz AM, Hawkins JA, Lu M, Cohen MS, Colan SD, Jaggers J, et al. Surgical management of complete atrioventricular septal defect: associations with surgical technique, age, and trisomy 21. J Thorac Cardiovasc Surg. 2011; 141(6):1371-9. https://doi.org/10.1016/j.jtcvs.2010.08.093.

15. Peterson JK, Setty SP, Knight JH, Thomas AS, Moller JH, Kochilas LK. Postoperative and long-term outcomes in children with trisomy 21 and single ventricle palliation. Congenit Heart Dis. 2019;14(5):854-63. https://doi. org/10.1111/chd.12823.

16. Wada N, Takahashi Y, Ando M, Park IS, Sasaki T. Single ventricle repair in children with Down's syndrome. Gen Thorac Cardiovasc Surg. 2008;56(3): 104-8. https://doi.org/10.1007/s11748-007-0201-z.

17. Kaulitz R, Ziemer G, Luhmer I, Kallfelz HC. Modified Fontan operation in functionally univentricular hearts: preoperative risk factors and intermediate results. J Thorac Cardiovasc Surg. 1996;112(3):658-64. https://doi.org/10.101 6/S0022-5223(96)70049-1.

18. Colquitt JL, Morris SA, Denfield SW, Fraser CD, Wang Y, Kyle WB. Survival in children with Down syndrome undergoing single-ventricle palliation. Ann Thorac Surg. 2016;101(5):1834-41. https://doi.org/10.1016/j.athoracsur.201 5.11.047.

19. Beghetti M, Rudzinski A, Zhang M. Efficacy and safety of oral sildenafil in children with Down syndrome and pulmonary hypertension. BMC Cardiovasc Disord. 2017;17(1):177. https://doi.org/10.1186/s12872-017-0569-3.

20. Cannon BC, Feltes TF, Fraley JK, Grifka RG, Riddle EM, Kovalchin JP. Nitric oxide in the evaluation of congenital heart disease with pulmonary hypertension: factors related to nitric oxide response. Pediatr Cardiol. 2005; 26(5):565-9. https://doi.org/10.1007/s00246-004-0767-5.

21. Duffels MG, Vis JC, van Loon RL, Nieuwkerk PT, van Dijk AP, Hoendermis ES, et al. Effect of bosentan on exercise capacity and quality of life in adults with pulmonary arterial hypertension associated with congenital heart disease with and without Down's syndrome. Am J Cardiol. 2009;103(9): 1309-15. https://doi.org/10.1016/j.amjcard.2009.01.021.

22. Polimenakos AC, Subramanian S, ElZein C, Ilbawi MN. Attrition in patients with single ventricle and trisomy 21: outcomes after a total cavopulmonary connection. Interact Cardiovasc Thorac Surg. 2017;24(5):747-54. https://doi. org/10.1093/icvts/ivw413.

23. Bush D, Galambos C, Dunbar Ivy D. Pulmonary hypertension in children with Down syndrome. Pediatr Pulmonol. 2021;56:621-9. https://doi.org/10.1 002/ppul.24687.

24. Clapp S, Perry BL, Farooki ZQ, Jackson WL, Karpawich PP, Hakimi M, et al. Down's syndrome, complete atrioventricular canal, and pulmonary vascular obstructive disease. J Thorac Cardiovasc Surg. 1990;100(1):115-21. https:// doi.org/10.1016/S0022-5223(19)35606-5.

25. Yamaki $\mathrm{S}$, Yasui $\mathrm{H}$, Kado H, Yonenaga K, Nakamura Y, Kikuchi T, et al. Pulmonary vascular disease and operative indications in complete atrioventricular canal defect in early infancy. J Thorac Cardiovasc Surg. 1993; 106(3):398-405. https://doi.org/10.1016/S0022-5223(19)34071-1.

26. Bando K, Turrentine MW, Sharp TG, Sekine Y, Aufiero TX, Sun K, et al. Pulmonary hypertension after operations for congenital heart disease: analysis of risk factors and management. J Thorac Cardiovasc Surg. 1996;1 12(6):1600-7; discussion 7-9. https://doi.org/10.1016/S0022-5223(96)70019-3.

27. Lindberg L, Olsson AK, Jögi $P$, Jonmarker C. How common is severe pulmonary hypertension after pediatric cardiac surgery? J Thorac Cardiovasc Surg. 2002;123(6):1155-63. https://doi.org/10.1067/mtc.2002.121497.

28. Schulze-Neick I, Li J, Penny DJ, Redington AN. Pulmonary vascular resistance after cardiopulmonary bypass in infants: effect on postoperative recovery. J Thorac Cardiovasc Surg. 2001;121(6):1033-9. https://doi.org/10.1067/mtc.2 001.113747

29. Wernovsky G, Wypij D, Jonas RA, Mayer JE Jr, Hanley FL, Hickey PR, et al. Postoperative course and hemodynamic profile after the arterial switch operation in neonates and infants. A comparison of low-flow cardiopulmonary bypass and circulatory arrest. Circulation. 1995;92(8):222635. https://doi.org/10.1161/01.CIR.92.8.2226.

30. Wessel DL. Hemodynamic responses to perioperative pain and stress in infants. Crit Care Med. 1993;21(9 Suppl):S361-2. https://doi.org/10.1097/ 00003246-199309001-00037.

31. Borland LM, Colligan J, Brandom BW. Frequency of anesthesia-related complications in children with Down syndrome under general anesthesia for noncardiac procedures. Paediatr Anaesth. 2004;14(9):733-8. https://doi. org/10.1111/j.1460-9592.2004.01329.x.

32. Carmosino MJ, Friesen RH, Doran A, Ivy DD. Perioperative complications in children with pulmonary hypertension undergoing noncardiac surgery or cardiac catheterization. Anesth Analg. 2007;104(3):521-7. https://doi.org/1 0.1213/01.ane.0000255732.16057.1c.

33. Wessel DL. Managing low cardiac output syndrome after congenital heart surgery. Crit Care Med. 2001;29(10 Suppl):S220-30. https://doi.org/10.1097/ 00003246-200110001-00004.

34. Jones KL, et al. Chromosomal Abnormality Syndromes Identifiable on Routine Karyotype. Smith's Recognizable Patterns of Human Malformation. 7th ed; 2013.

35. Bull MJ. Health supervision for children with Down syndrome. Pediatrics. 2011;128(2):393-406. https://doi.org/10.1542/peds.2011-1605.

36. Colvin KL, Yeager ME. What people with Down Syndrome can teach us about cardiopulmonary disease. Eur Respir Rev. 2017;26(143):160098. https:// doi.org/10.1183/16000617.0098-2016. PMID: 28223397. 
37. Uppal H, Chandran S, Potluri R. Risk factors for mortality in Down syndrome. J Intellect Disabil Res. 2015;59(9):873-81. https://doi.org/10.1111/jir.12196.

38. Pandit C, Fitzgerald DA. Respiratory problems in children with Down syndrome. J Paediatr Child Health. 2012;48(3):E147-52. https://doi.org/1 0.1111/j.1440-1754.2011.02077.x.

39. Fitzgerald DA, Paul A, Richmond C. Severity of obstructive apnoea in children with Down syndrome who snore. Arch Dis Child. 2007;92(5):423-5. https://doi.org/10.1136/adc.2006.111591.

40. Maris M, Verhulst S, Wojciechowski M, Van de Heyning P, Boudewyns A. Prevalence of obstructive sleep apnea in children with Down syndrome Sleep. 2016;39(3):699-704. https://doi.org/10.5665/sleep.5554.

41. Fan Z, Ahn M, Roth HL, Li L, Vaughn BV. Sleep Apnea and Hypoventilation in Patients with Down Syndrome: Analysis of 144 Polysomnogram Studies. Children (Basel). 2017;4(7):55. https://doi.org/10.3390/children4070055. PMID: 28665356; PMCID: PMC5532547.

42. Farhood Z, Isley JW, Ong AA, Nguyen SA, Camilon TJ, LaRosa AC, et al. Adenotonsillectomy outcomes in patients with Down syndrome and obstructive sleep apnea. Laryngoscope. 2017;127(6):1465-70. https://doi. org/10.1002/lary.26398.

43. Ingram DG, Ruiz AG, Gao D, Friedman NR. Success of tonsillectomy for obstructive sleep apnea in children with Down syndrome. J Clin Sleep Med. 2017;13(8):975-80. https://doi.org/10.5664/jcsm.6698.

44. Nation J, Brigger M. The efficacy of Adenotonsillectomy for obstructive sleep apnea in children with Down syndrome: a systematic review. Otolaryngol Head Neck Surg. 2017;157(3):401-8. https://doi.org/10.1177/01 94599817703921.

45. Thottam PJ, Choi S, Simons JP, Kitsko DJ. Effect of Adenotonsillectomy on central and obstructive sleep apnea in children with Down syndrome. Otolaryngol Head Neck Surg. 2015;153(4):644-8. https://doi.org/10.1177/01 94599815587877.

46. Martha VF, Moreira Jda S, Martha AS, Velho FJ, Eick RG, Goncalves SC. Reversal of pulmonary hypertension in children after adenoidectomy or adenotonsillectomy. Int J Pediatr Otorhinolaryngol. 2013;77(2):237-40. https://doi.org/10.1016/j.ijporl.2012.11.006.

47. Acar O, Üner A, Garça MF, Ece I, Epçaçan S, Turan M, et al. The effect of tonsillectomy and adenoidectomy on right ventricle function and pulmonary artery pressure by using Doppler echocardiography in children. Clin Exp Otorhinolaryngol. 2016;9(2):163-7. https://doi.org/10.21053/ceo.2015.00087.

48. Ram G, Chinen J. Infections and immunodeficiency in Down syndrome. Clin Exp Immunol. 2011;164(1):9-16. https://doi.org/10.1111/j.1365-2249.2011. 04335.x.

49. Hilton JM, Fitzgerald DA, Cooper DM. Respiratory morbidity of hospitalized children with trisomy 21. J Paediatr Child Health. 1999;35(4):383-6. https:// doi.org/10.1046/j.1440-1754.1999.00386.x.

50. Bloemers BL, Broers CJ, Bont L, Weijerman ME, Gemke RJ, van Furth AM. Increased risk of respiratory tract infections in children with Down syndrome: the consequence of an altered immune system. Microbes Infect. 2010;12(11):799-808. https://doi.org/10.1016/j.micinf.2010.05.007.

51. Bruijn $M$, van der $A a L B$, van Rijn RR, Bos AP, van Woensel JB. High incidence of acute lung injury in children with Down syndrome. Intensive Care Med. 2007;33(12):2179-82. https://doi.org/10.1007/s00134007-0803-z.

52. Henry E, Walker D, Wiedmeier SE, Christensen RD. Hematological abnormalities during the first week of life among neonates with Down syndrome: data from a multihospital healthcare system. Am J Med Genet A. 2007;143a(1):42-50.

53. Ross JA, Spector LG, Robison LL, Olshan AF. Epidemiology of leukemia in children with Down syndrome. Pediatr Blood Cancer. 2005;44(1):8-12. https://doi.org/10.1002/pbc.20165.

54. Satgé $D$, Seidel MG. The pattern of malignancies in Down syndrome and its potential context with the immune system. Front Immunol. 2018;9:3058. https://doi.org/10.3389/fimmu.2018.03058.

55. Chen MH, Chen SJ, Su LY, Yang W. Thyroid dysfunction in patients with Down syndrome. Acta Paediatr Taiwan. 2007;48(4):191-5.

56. Murphy J, Philip M, Macken S, Meehan J, Roche E, Mayne PD, et al. Thyroid dysfunction in Down's syndrome and screening for hypothyroidism in children and adolescents using capillary TSH measurement. J Pediatr Endocrinol Metab. 2008;21(2):155-63.

57. Karlsson B, Gustafsson J, Hedov G, Ivarsson SA, Annerén G. Thyroid dysfunction in Down's syndrome: relation to age and thyroid autoimmunity. Arch Dis Child. 1998;79(3):242-5. https://doi.org/10.1136/adc.79.3.242.
58. Pilchard J, Dadlani G, Andropoulos D, Jacobs JP, Cooper DS. Intensive care and perioperative management of patients with complete atrioventricular septal defect. World J Pediatr Congenit Heart Surg. 2010;1(1):105-11. https:// doi.org/10.1177/2150135109360815.

59. Bettendorf M, Schmidt KG, Tiefenbacher U, Grulich-Henn J, Heinrich UE, Schönberg DK. Transient secondary hypothyroidism in children after cardiac surgery. Pediatr Res. 1997;41(3):375-9. https://doi.org/10.1203/00006450-1 99703000-00012.

60. Toscano E, Pacileo G, Limongelli G, Verrengia M, Di Mita O, Di Maio S, et al. Subclinical hypothyroidism and Down's syndrome; studies on myocardial structure and function. Arch Dis Child. 2003;88(11):1005-8. https://doi.org/1 0.1136/adc.88.11.1005.

61. Dimmick S, Badawi N, Randell T. Thyroid hormone supplementation for the prevention of morbidity and mortality in infants undergoing cardiac surgery. Cochrane Database Syst Rev. 2004;3:Cd004220.

62. Malt EA, Dahl RC, Haugsand TM, Ulvestad IH, Emilsen NM, Hansen B, et al. Health and disease in adults with Down syndrome. Tidsskr Nor Laegeforen. 2013;133(3):290-4. https://doi.org/10.4045/tidsskr.12.0390.

63. Dinani S, Carpenter S. Down's syndrome and thyroid disorder. J Ment Defic Res. 1990;34(Pt 2):187-93.

64. Prasher VP. Reliability of diagnosing clinical hypothyroidism in adults with Down syndrome. Aust N Z J Dev Disabil. 1995;20(3):223-33. https://doi. org/10.1080/07263869500035571.

65. Baird PA, Sadovnick AD. Causes of death to age 30 in Down syndrome. Am J Hum Genet. 1988;43(3):239-48.

66. Bell AJ, Bhate MS. Prevalence of overweight and obesity in Down's syndrome and other mentally handicapped adults living in the community. J Intellect Disabil Res. 1992;36(Pt 4):359-64.

67. Murdoch JC, Rodger JC, Rao SS, Fletcher CD, Dunnigan MG. Down's syndrome: an atheroma-free model? Br Med J. 1977;2(6081):226-8. https:// doi.org/10.1136/bmj.2.6081.226

68. Ylä-Herttuala S, Luoma J, Nikkari T, Kivimäki T. Down's syndrome and atherosclerosis. Atherosclerosis. 1989;76(2-3):269-72. https://doi.org/10.1016/ 0021-9150(89)90110-X

69. Anwar AJ, Walker JD, Frier BM. Type 1 diabetes mellitus and Down's syndrome: prevalence, management and diabetic complications. Diabet Med. 1998;15(2):160-3. https://doi.org/10.1002/(SICI)1096-9136(199802)15:2< 160::AID-DIA537>3.0.CO;2-J.

70. Van Dyke DCHD, Dyken ME. Alzheimer's disease and Down syndrome. Down Syndr Q. 1998:3:1-11.

71. Gual N, Morandi A, Pérez LM, Brítez L, Burbano P, Man F, et al. Risk factors and outcomes of delirium in older patients admitted to Postacute care with and without dementia. Dement Geriatr Cogn Disord. 2018;45(1-2):121-9. https://doi.org/10.1159/000485794.

72. Barnett ML, Press KP, Friedman D, Sonnenberg EM. The prevalence of periodontitis and dental caries in a Down's syndrome population. J Periodontol. 1986;57(5):288-93. https://doi.org/10.1902/jop.1986.57.5.288.

73. Statter MB, Noritz G; COMMITTEE ON BIOETHICS, COUNCIL ON CHILDREN WITH DISABILITIES. Children With Intellectual and Developmental Disabilities as Organ Transplantation Recipients. Pediatrics. 2020;145(5):e20200625. https://doi.org/10.1542/peds.2020-0625. Epub 2020 Apr 20. PMID: 32312907.

74. Kavarana MN, Turnbull JM, Sade RM. Should a Down syndrome child with a failing heart be offered heart transplantation? Ann Thorac Surg. 2017;104(4): 1111-6. https://doi.org/10.1016/j.athoracsur.2017.06.041.

75. Henriksen KJ, Chang A, Bayliss GP. Kidney transplant outcomes in 2 adults with Down syndrome. Kidney Int Rep. 2018;3(4):979-84. https://doi.org/10.1 016/j.ekir.2018.02.006.

76. Broda CR, Cabrera AG, Rossano JW, Jefferies JL, Towbin JA, Chin C, et al. Cardiac transplantation in children with Down syndrome, turner syndrome, and other chromosomal anomalies: a multi-institutional outcomes analysis. J Heart Lung Transplant. 2018;37(6):749-54. https://doi.org/10.1016/j.healun.2 018.01.1296.

77. Baqi N, Tejani A, Sullivan EK. Renal transplantation in Down syndrome: a report of the north American pediatric renal transplant cooperative study. Pediatr Transplant. 1998;2(3):211-5.

78. Leonard H, Eastham K, Dark J. Heart and heart-lung transplantation in Down's syndrome. The lack of supportive evidence means each case must be carefully assessed. Bmj. 2000;320(7238):816-7. https://doi.org/10.1136/ bmj.320.7238.816.

79. Wightman A, Diekema D, Goldberg A. Consideration of children with intellectual disability as candidates for solid organ transplantation-A practice 
in evolution. Pediatr Transplant. 2018;22(1). https://doi.org/10.1111/petr.13 091. Epub 2017 Dec 7. PMID: 29218833.

80. Goel AN, lyengar A, Schowengerdt K, Fiore AC, Huddleston CB. Heart transplantation in children with intellectual disability: An analysis of the UNOS database. Pediatr Transplant. 2017;21(2). https://doi.org/10.1111/ petr.12858. Epub 2016 Dec 9. PMID: 27933693.

81. Overby KJ, Fins JJ. Organ transplantation for individuals with neurodevelopmental disorders. Camb Q Healthc Ethics. 2016;25(2):272-81. https://doi.org/10.1017/S0963180115000572.

82. Yamakawa S, Nagai T, Uemura O. Down syndrome and mild kidney dysfunction. Pediatr Int. 2018;60(4):391-3. https://doi.org/10.1111/ped.13525.

83. Niamien-Attai C, Bacchetta J, Ranchin B, Sanlaville D, Cochat P. Renal abnormalities in Down syndrome: a review. Arch Pediatr. 2017;24(10):10138. https://doi.org/10.1016/j.arcped.2017.07.014.

84. Hitzler JK, He W, Doyle J, Cairo M, Camitta BM, Chan KW, et al. Outcome of transplantation for acute myelogenous leukemia in children with Down syndrome. Biol Blood Marrow Transplant. 2013;19(6):893-7. https://doi.org/1 0.1016/j.bbmt.2013.02.017.

85. Mittal S, Boan AD, Pereira-Smith S, LaRosa A. Screening for Anemia in children with Down syndrome. J Dev Behav Pediatr. 2020;41(2):141-4. https://doi.org/10.1097/DBP.0000000000000731.

86. Suzuki K, Muramatsu H, Okuno Y, Narita A, Hama A, Takahashi Y, et al. Immunosuppressive therapy for patients with Down syndrome and idiopathic aplastic anemia. Int J Hematol. 2016;104(1):130-3. https://doi. org/10.1007/s12185-016-1997-Z.

87. Furuya A, Ishida M, Hodohara K, Yoshii M, Okuno H, Horinouchi A, et al. Epstein-Barr virus-related post-transplant lymphoproliferative disorder occurring after bone marrow transplantation for aplastic anemia in Down's syndrome. Int J Clin Exp Pathol. 2014;7(1):438-42.

88. Schoch J, Rohrer TR, Kaestner M, Abdul-Khaliq H, Gortner L, Sester U, et al. Quantitative, Phenotypical, and functional characterization of cellular immunity in children and adolescents with Down syndrome. J Infect Dis. 2017;215(10):1619-28. https://doi.org/10.1093/infdis/jix168.

89. Mehra MR, Canter CE, Hannan MM, Semigran MJ, Uber PA, Baran DA, et al. The 2016 International Society for Heart Lung Transplantation listing criteria for heart transplantation: a 10-year update. J Heart Lung Transplant. 2016; 35(1):1-23. https://doi.org/10.1016/j.healun.2015.10.023.

90. Tong A, Jan S, Wong G, Craig JC, Irving M, Chadban S, et al. Rationing scarce organs for transplantation: healthcare provider perspectives on wait-listing and organ allocation. Clin Transpl. 2013;27(1):60-71. https://doi.org/10.1111/ctr.12004.

91. Lewanda AF, Matisoff A, Revenis M, Harahsheh A, Futterman C, Nino G, et al. Preoperative evaluation and comprehensive risk assessment for children with Down syndrome. Paediatr Anaesth. 2016;26(4):356-62. https:// doi.org/10.1111/pan.12841.

92. Hamilton J, Yaneza MM, Clement WA, Kubba H. The prevalence of airway problems in children with Down's syndrome. Int J Pediatr Otorhinolaryngol. 2016;81:1-4. https://doi.org/10.1016/j.jporl.2015.11.027.

93. Shott SR. Down syndrome: common otolaryngologic manifestations. Am J Med Genet C Semin Med Genet. 2006;142c(3):131-40.

94. Jacobs IN, Gray RF, Todd NW. Upper airway obstruction in children with Down syndrome. Arch Otolaryngol Head Neck Surg. 1996;122(9):945-50. https://doi.org/10.1001/archotol.1996.01890210025007.

95. Shott SR. Down syndrome: analysis of airway size and a guide for appropriate intubation. Laryngoscope. 2000;1 10(4):585-92. https://doi.org/1 0.1097/00005537-200004000-00010

96. Bai W, Voepel-Lewis T, Malviya S. Hemodynamic changes in children with Down syndrome during and following inhalation induction of anesthesia with sevoflurane. J Clin Anesth. 2010;22(8):592-7. https://doi.org/10.1016/j. jclinane.2010.05.002.

97. Kraemer FW, Stricker PA, Gurnaney HG, McClung H, Meador MR, Sussman E, et al. Bradycardia during induction of anesthesia with sevoflurane in children with Down syndrome. Anesth Analg. 2010;111(5):1259-63. https:// doi.org/10.1213/ANE.0b013e3181f2eacf.

98. Simsic JM, Coleman K, Maher KO, Cuadrado A, Kirshbom PM. Do neonates with genetic abnormalities have an increased morbidity and mortality following cardiac surgery? Congenit Heart Dis. 2009;4(3):160-5. https://doi. org/10.1111/j.1747-0803.2009.00281.x.

99. Doell C, Bernet V, Molinari L, Beck I, Balmer C, Latal B. Children with genetic disorders undergoing open-heart surgery: are they at increased risk for postoperative complications? Pediatr Crit Care Med. 2011;12(5):539-44. https://doi.org/10.1097/PCC.0b013e3181fe4085.
100. Evans JM, Dharmar M, Meierhenry E, Marcin JP, Raff GW. Association between Down syndrome and in-hospital death among children undergoing surgery for congenital heart disease: a US population-based study. Circ Cardiovasc Qual Outcomes. 2014;7(3):445-52. https://doi.org/1 0.1161/CIRCOUTCOMES.113.000764

101. Buchwald MA, Laasner U, Balmer C, Cannizzaro V, Latal B, Bernet V. Comparison of postoperative chylothorax in infants and children with trisomy 21 and without dysmorphic syndrome: is there a difference in clinical outcome? J Pediatr Surg. 2019;54(7):1298-302. https://doi.org/10.101 6/j.jpedsurg.2018.06.032.

102. Malec E, Mroczek T, Pajak J, Januszewska K, Zdebska E. Results of surgical treatment of congenital heart defects in children with Down's syndrome. Pediatr Cardiol. 1999;20(5):351-4. https://doi.org/10.1007/s002469900483.

103. Moerman P, Vandenberghe $K$, Devlieger $H$, Van Hole C, Fryns JP, Lauweryns JM Congenital pulmonary lymphangiectasis with chylothorax: a heterogeneous lymphatic vessel abnormality. Am J Med Genet. 1993;47(1):54-8.

104. Martínez-Quintana E, Rodríguez-González F, Medina-Gil JM, Agredo-Muñoz J, Nieto-Lago V. Clinical outcome in Down syndrome patients with congenital heart disease. Cir Cir. 2010;78(3):245-50.

105. Masuda M, Kado H, Tanoue Y, Fukae K, Onzuka T, Shiokawa Y, et al. Does Down syndrome affect the long-term results of complete atrioventricular septal defect when the defect is repaired during the first year of life? Eur J Cardiothorac Surg. 2005;27(3):405-9. https://doi.org/10.1016/.ejcts.2004.11.027.

106. Lange R, Guenther T, Busch R, Hess J, Schreiber C. The presence of Down syndrome is not a risk factor in complete atrioventricular septal defect repair. J Thorac Cardiovasc Surg. 2007;134(2):304-10. https://doi.org/10.1016/ j.jtcvs.2007.01.026.

107. Tucker EM, Pyles LA, Bass JL, Moller JH. Permanent pacemaker for atrioventricular conduction block after operative repair of perimembranous ventricular septal defect. J Am Coll Cardiol. 2007:50(12):1196-200. https:// doi.org/10.1016/j.jacc.2007.06.014.

108. Blom NA, Ottenkamp J, Deruiter MC, Wenink AC, Gittenberger-de Groot AC. Development of the cardiac conduction system in atrioventricular septal defect in human trisomy 21. Pediatr Res. 2005;58(3):516-20. https://doi.org/1 0.1203/01.PDR.0000179388.10921.44.

109. Desai AR, Branco RG, Comitis GA, Maiya S, Vyas DB, Vaz Silva P, et al. Early postoperative outcomes following surgical repair of complete atrioventricular septal defects: is Down syndrome a risk factor? Pediatr Crit Care Med. 2014;15(1):35-41. https://doi.org/10.1097/PCC.0000000000000004.

110. Di Mambro C, Calvieri C, Silvetti MS, Tamburri I, Giannico S, Baban A, et al. Bradyarrhythmias in repaired Atrioventricular Septal defects: single-center experience based on 34 years of follow-up of 522 patients. Pediatr Cardiol. 2018;39(8):1590-7. https://doi.org/10.1007/s00246-018-1934-4.

111. Houck CA, Evertz R, Teuwen CP, Roos-Hesselink JW, Kammeraad JAE, Duijnhouwer AL, et al. Dysrhythmias in patients with a complete atrioventricular septal defect: from surgery to early adulthood. Congenit Heart Dis. 2019;14(2):280-7. https://doi.org/10.1111/chd.12724.

112. Cashen K, Thiagarajan RR, Collins JW Jr, Rycus PT, Backer CL, Reynolds M, et al. Extracorporeal membrane oxygenation in pediatric trisomy 21:30 years of experience from the extracorporeal life support organization registry. J Pediatr. 2015:167(2):403-8. https://doi.org/10.1016/.jpeds.2015.04.048.

113. Gupta P, Gossett JM, Rycus PT, Prodhan P. Extracorporeal membrane oxygenation in children with heart disease and Down syndrome: a multicenter analysis. Pediatr Cardiol. 2014;35(8):1421-8.

114. Barbaro RP, Paden ML, Guner YS, Raman L, Ryerson LM, Alexander P, et al. Pediatric extracorporeal life support organization registry international report 2016. ASAIO J. 2017;63(4):456-63. https://doi.org/10.1097/MAT. 0000000000000603

115. Mafrica F, Fodale V. Opioids and Down's syndrome. J Opioid Manag. 2006; 2(2):93-8. https://doi.org/10.5055/jom.2006.0015.

116. Gakhal B, Scott CS, MacNab AJ. Comparison of morphine requirements for sedation in Down's syndrome and non-Down's patients following paediatric cardiac surgery. Paediatr Anaesth. 1998;8(3):229-33. https://doi.org/10.1046/ j.1460-9592.1998.00764.x.

117. Valkenburg AJ, van Dijk M, de Leeuw TG, Meeussen CJ, Knibbe CA, Tibboel D. Anaesthesia and postoperative analgesia in surgical neonates with or without Down's syndrome: is it really different? Br J Anaesth. 2012;108(2): 295-301. https://doi.org/10.1093/bja/aer421.

118. Van Driest SL, Shah A, Marshall MD, Xu H, Smith AH, McGregor TL, et al. Opioid use after cardiac surgery in children with Down syndrome. Pediatr Crit Care Med. 2013;14(9):862-8. https://doi.org/10.1097/PCC.0b013e31829f5d9d. 
119. Goot BH, Kaufman J, Pan Z, Bourne DWA, Hickey F, Twite M, et al. Morphine pharmacokinetics in children with Down syndrome following cardiac surgery. Pediatr Crit Care Med. 2018;19(5):459-67. https://doi.org/10.1097/ PCC.0000000000001537.

120. Valkenburg AJ, Calvier EA, van Dijk M, Krekels EH, O'Hare BP, Casey WF, et al. Pharmacodynamics and pharmacokinetics of morphine after cardiac surgery in children with and without Down syndrome. Pediatr Crit Care Med. 2016; 17(10):930-8. https://doi.org/10.1097/PCC.0000000000000904.

121. Mian P, Valkenburg AJ, Allegaert K, Koch BCP, Breatnach CV, Knibbe CAJ, et al. Population pharmacokinetic modeling of acetaminophen and metabolites in children after cardiac surgery with cardiopulmonary bypass. J Clin Pharmacol. 2019;59(6):847-55. https://doi.org/10.1002/jcph.1373.

122. Horvath R, Halbrooks EF, Overman DM, Friedrichsdorf SJ. Efficacy and safety of postoperative Dexmedetomidine Administration in Infants and Children Undergoing Cardiac Surgery: a retrospective cohort study. J Pediatr Intensive Care. 2015;4(3):138-45. https://doi.org/10.1055/s-0035-1559820.

123. Jadcherla SR, Vijayapal AS, Leuthner S. Feeding abilities in neonates with congenital heart disease: a retrospective study. J Perinatol. 2009;29(2):112-8. https://doi.org/10.1038/jp.2008.136.

124. Poskanzer SA, Hobensack VL, Ciciora SL, Santoro SL. Feeding difficulty and gastrostomy tube placement in infants with Down syndrome. Eur J Pediatr. 2020;179(6):909-17. https://doi.org/10.1007/s00431-020-03591-x.

125. Zemel BS, Pipan M, Stallings VA, Hall W, Schadt K, Freedman DS, et al. Growth charts for children with Down syndrome in the United States. Pediatrics. 2015;136(5):e1204-11. https://doi.org/10.1542/peds.2015-1652.

126. Bravo-Valenzuela NJ, Passarelli ML, Coates MV, Nascimento LF. Weight and height recovery in children with Down syndrome and congenital heart disease. Rev Bras Cir Cardiovasc. 2011;26(1):61-8.

127. Purifoy ET, Spray BJ, Riley JS, Prodhan P, Bolin EH. Effect of trisomy 21 on postoperative length of stay and non-cardiac surgery after complete repair of tetralogy of Fallot. Pediatr Cardiol. 2019;40(8):1627-32. https://doi.org/10.1 007/s00246-019-02196-y.

128. Mackman CA, Loomba RS, Slicker J, Bartz PJ. Growth trajectory in children with trisomy 21 with and without Atrioventricular Septal defect. Congenit Heart Dis. 2016;11(4):348-53. https://doi.org/10.1111/chd.12378.

129. Bauer J, Teufel U, Doege C, Hans-Juergen G, Beedgen B, Linderkamp O. Energy expenditure in neonates with Down syndrome. J Pediatr. 2003; 143(2):264-6. https://doi.org/10.1067/50022-3476(03)00327-5.

130. Sica CD, Cesa CC, Pellanda LC. Growth curves in Down syndrome with congenital heart disease. Rev Assoc Med Bras (1992). 2016;62(5):414-20.

131. O'Neill KL, Shults J, Stallings VA, Stettler N. Child-feeding practices in children with Down syndrome and their siblings. J Pediatr. 2005;146(2):2348. https://doi.org/10.1016/j.jpeds.2004.10.045.

132. Santos F, Croti UA, Marchi CH, Murakami AN, Brachine JDP, Borim BC, et al. Surgical treatment for congenital heart defects in Down syndrome patients. Braz J Cardiovasc Surg. 2019;34(1):1-7. https://doi.org/10.21470/1678-9741-2 018-0358.

133. Malviya S, Voepel-Lewis T, Siewert M, Pandit UA, Riegger LQ, Tait AR. Risk factors for adverse postoperative outcomes in children presenting for cardiac surgery with upper respiratory tract infections. Anesthesiology. 2003; 98(3):628-32. https://doi.org/10.1097/00000542-200303000-00009.

134. Beckhaus AA, Castro-Rodriguez JA. Down Syndrome and the Risk of Severe RSV Infection: A Meta-analysis. Pediatrics. 2018;142(3):e20180225. https://doi. org/10.1542/peds.2018-0225. Epub 2018 Aug 9. PMID: 30093540.

135. Bunt CW, Bunt SK. Role of the family physician in the care of children with Down syndrome. Am Fam Physician. 2014;90(12):851-8.

\section{Publisher's Note}

Springer Nature remains neutral with regard to jurisdictional claims in published maps and institutional affiliations.

Ready to submit your research? Choose BMC and benefit from:

- fast, convenient online submission

- thorough peer review by experienced researchers in your field

- rapid publication on acceptance

- support for research data, including large and complex data types

- gold Open Access which fosters wider collaboration and increased citations

- maximum visibility for your research: over $100 \mathrm{M}$ website views per year

At BMC, research is always in progress.

Learn more biomedcentral.com/submissions 